\title{
“West Germans Don't Even Know about it": An Analysis of Narrations by East German COMECON Pipeline Workers after the Fall of the Wall.
}

\author{
JEANNETTE PROCHNOW \\ Bielefeld University \\ jeannette.prochnow@uni-bielefeld.de
}

\begin{abstract}
The paper is concerned with communicative practices of former GDR contract workers who were involved in the construction of a trans-national pipeline in the former Soviet Union, in the 1970s and 1980s. This paper draws on the ethnography of communication to investigate the narratives of former GDR pipeline workers about perceived divisions between 'East and West'. This idea of 'East and West' is elaborated in the text. In particular, the study will look at the workers' heartfelt sense that their accomplishments have been neglected since Germany's reunification. For this purpose, the article will focus on the contexts and linguistic devices by which former pipeline workers construct a narrative on divisions between 'East and West'. It is assumed that the communicative practices are not a merely nostalgic or even revisionist appeal to the GDR; rather, former pipeline workers represent a critique of the transitional process informed by their unique biographical experience.
\end{abstract}

Key words: East-West juxtaposition, memory, narrative, oblivion, pride, unification

\section{Introduction}

On 11 J uly 2008, Wolfgang Tiefensee, the German Minister of Transport and Traffic, Alexander Petrow, the Russian Ambassador to Germany, Alexej Miller, the CEO of the energy company OAO Gazprom, Klaus Ewald Holst, the CEO of the Verbundnetz Gas AG, ${ }^{1}$ one of Germany's market leaders in the import of natural gas, and other leading personalities from politics and economics celebrated the $35^{\text {th }}$ anniversary of gas supply from the Russian Federation to Germany, in the East German city of Leipzig. ${ }^{2}$ Today, Russian supplies of natural gas cover 37\% of Germany's requirements. For this reason, the latest German Federal Government's report on its oil and gas market strategy stated:

Russia is our most important energy supplier [...]. The previous activities of German companies in the former Soviet Union have paid off, in particular regarding natural gas [...]. Over the past decades, Russia has always proved to be a reliable supplier. ${ }^{3}$

\footnotetext{
${ }^{1}$ Verbundnetz Gas Aktiengesellschaft (Verbundnetz Gas Group).

2 Wirtschaftskurier, 35J ahre Erdgas aus Russland für Deutschland, August 2008.

${ }^{3}$ Bundesministerium für Wirtschaft und Technologie, Bericht der Bundesregierung zur Öl- und Gasmarktstrategie, November 2008, <http://www.bmwi.de/ BMWi/Navigation/Service/suche.html>, accessed 19th of February, 2010.
} 
In fact, the West German energy company Ruhrgas AG, known as Eon Ruhrgas today, had signed a contract as early as 1970 with the Soviet state 4 to guarantee the West German energy supply, as did the government of the former GDR represented by the East German energy monopolist VEB Verbundnetz, ${ }^{5}$ now called Verbundnetz Gas AG. Today, Eon Ruhrgas, Verbundnetz Gas AG and the former Soviet state-owned company OAO Gazprom are the key players in the German-Russian energy business. The bilateral cooperation between Germany and Russia on the energy market has been transformed relatively little in regard to the companies and in many cases even the management personnel involved since 1989. In contrast, former GDR pipeline workers have had to struggle with a considerable break in life continuities, doubts concerning their professional identities and loss of recognition with the fall of the Wall and Germany's reunification in 1990. Today, not many people in the political and economic field give credit to the fact, that the pipeline workers from the former GDR were instrumental in constructing one of the core pipelines and the associated infrastructure still in use today. It can be argued that the costs of rebuilding East German society as well as the reorganisation of its economy and its political system have been unequally distributed and certain groups have had to carry more social burdens than others. However, twenty years after the fall of the Berlin Wall, the confusion that accompanied the structural transformations in the 1990s has certainly dissipated. Paradoxically, it is in this becalmed situation that people have not only started to reflect critically on the transformation process but also to express political and social interests.

This article is concerned with current communicative practices of former GDR contract workers who were involved in the construction of a transnational pipeline in the former Soviet Union in the 1970s and 1980s. The economic venture took place under the auspices of an intergovernmental $\mathrm{COMECON}^{6}$ agreement and was set in an allembracing ideological campaign launched by the East German Socialist Party (SED), ${ }^{7}$ which referred to the pipeline builders as Kader (Cadres, or an elite team of workers). With Germany's reunification and the accompanying transformation process, former pipeline workers have experienced a dramatic loss of social prestige, and the venture has been forgotten by the German public.

For many years, Trassenvereine (pipeline commemorative associations), founded by former pipeline workers, have developed cultural practices leading to a shared group identity. Negotiating the past at diverse communicative events, they constitute a vivid narrative community. Inside the communicative infrastructure of the group, a variety of topics are addressed such as career paths after the breakdown of socialism, the Orange Revolution in Ukraine, transformations in East Germany after the changeover in 1989,

(author's translation of the German original: „Russland ist unser größter Energielieferant und wir wiederum der größte Energieabnehmer Russlands [...] Das frühere Engagement deutscher Unternehmen in der damaligen Sowjetunion zahlt sich jetzt vor allem bei Gas aus [...] In den vergangenen J ahrzehnten hat sich Russland stets als verlässlicher Lieferant erwiesen.")

${ }^{4}$ Wirtschaftskurier, op. cit.

${ }^{5}$ Volkseigener Betrieb Verbundnetz (people-owned enterprise Verbundnetz).

${ }^{6}$ The Council for Mutual Assistance was founded in 1949 and basically constituted the "socialist counterpart" to the Organisation for European Economic Co-operation that emerged from the Marshall Plan and later to the European Economic Community.

${ }^{7}$ Sozialistische Einheitspartei Deutschlands (Socialist Unity Party of Germany). 
and their work and life in the Soviet Union to name only a random selection. In the following, the narratives of former pipeline workers on divisions between East and West' will be examined, particularly in regard to the workers' heartfelt sense of negligence concerning their work accomplishments. This idea of 'East and West' is not only used by the community of pipeline workers to compare East Germans to West Germans and to juxtapose socialist and capitalist economies, but also to compare professional life before and after 1989.

Starting with the assumption that the pipeline workers' narrative alternates between striving for recognition of their achievement and resistance to a loss of prestige brought about by what they perceive as a lack of public awareness, it is hypothesised that the communicative practices are not merely a nostalgic or even a revisionist appeal to the GDR past. Rather, they represent a critique of the transitional process in Germany informed by the pipeline workers' exceptional biographical narrative.

First of all, it is necessary to give an overview of the historical background of the COMECON pipeline construction with special regard to the role the pipeline workers played in the campaigns of the political GDR elites. After this, the research design of the study will be illustrated. The paper will then turn to today's former pipeline builders' practices of communicative appeal to the past, focussing on the narrative construction of pride as a means of resistance to social oblivion and then to practices of revitalisation of socialist semiotics. As a final step, the paper will illustrate how expressions of pride intermingle with interpretative patterns of 'East and West'.

\section{Historical Background: Pipeline Builders as Socialist Hero Workers}

In June 1974, delegates of former COMECON member states signed the General Agreement on Economic Collaboration to tap natural gas resources near Orenburg in the then Soviet Union. ${ }^{8}$

The first pipeline section was built between 1974 and 1978 in Ukraine. This section was named "Drushba-Trasse", a combination of the Russian word for friendship and an explicitly East German term for pipeline. A second pipeline section starting in the Ural Mountains near the city of Perm was built from 1982-93. Altogether, approximately 15,000 mostly young, male workers were mobilised $^{9}$ and worked in the Soviet Union for up to 10 years. People applied voluntarily ${ }^{10}$ for a contract within the framework of pipeline construction that also included affiliated obligations such as the development of the general infrastructure and dwelling places along the pipeline for the future Soviet operators.

\footnotetext{
${ }^{8}$ Czechoslovak Socialist Republic, People's Republic of Bulgaria, German Democratic Republic, People's Republic of Poland, People's Republic of Hungary and Soviet Union.

9 K. Belwe, ,Zentrales Jugendobjekt der FDJ "Erdgastrasse”, Gesamtdeutsches Institut, Bundesanstalt für Gesamtdeutsche Aufgaben, Analysen und Berichte, II 1 - 191 12, Bonn, 1983.

10 In a survey conducted in 1987 (earlier data unfortunately is not available yet), 89.6\% of the respondents stated that they applied independently, $9.7 \%$ that they were recruited. (Zentralinstitut für J ugendforschung Leipzig (ed.), "Zum Einsatz J ugendlicher and der Erdgastrasse in der SU', Codebuch DJ I-Studien-Nr. A48, Leipzig 1987).
} 
The whole project was officially realised under the patronage of the socialist youth organisation FDJ ${ }^{11}$. For this reason the economic venture was declared to be a "Youth Project"12 by Klaus Siebold, Minister of Coal mining and Energy in the SED. Hence, the majority of the pipeline workers were FDJ members who were "delegated" to the pipeline project by their home factories. Older employees also came, mainly experienced construction supervisors and engineers but also doctors, economists and police officers. In general, these workers were either members of the SED or were functionaries of the SED, which had a permanent office at the construction site.

Most of the former pipeline workers today state that they applied for a job with the venture because of the alluring prospects of high earnings, access to rare consumer goods by means of an exclusive shopping catalogue (GENEX) or simply the allocation of an apartment or university admission. ${ }^{13}$ They also refer to the fact that the "Youth Project" offered them the opportunity to see another country and to experience a great adventure. Even if all this was subjectively true, it is also obvious that it was nearly impossible to escape from the symbolic and ritual performance of the socialist mass organisations. It can be assumed that for many of them, their individual motives clashed with the elite's interests, whereas others undoubtedly were convinced of the political and ideological principles of the FDJ and SED.

The trans-national economic operation was set in an all-embracing ideological campaign launched by the SED and carried out by its sub-institutions. The pipeline construction was declared to be the "Economic Event of the Century", that could provide a substantial technical basis for a joint communist future ${ }^{14}$ and to bring about world peace by standing up to the imperial USA and at the same time integrating West Germany into the venture. ${ }^{15}$ Given the fact that the political elites of the GDR conceived of and discursively constructed the East German state as a labour state, the young "hero worker"16 constituted the core of this campaign. Pipeline-builders were invited by school classes and factory brigades to report on their lives and work in the "brother-state", and individual pipeline workers or whole brigades were awarded a range of national honours by the head of state, Erich Honecker. ${ }^{17}$ While the political propaganda of the 1970s and 1980s in the GDR generally proved to be lacking in appropriate heroes for the cause, ${ }^{18}$ pipeline builders served the media as protagonists in the promotion of socialism. Thus, the economic venture was turned into an issue which caught the headlines in the East

\footnotetext{
${ }^{11}$ Freie Deutsche J ugend (Free German Youth)

${ }^{12}$ From the very foundation of the FDJ, the organisation was also conceptualised as an economic reserve at the Socialist Party's disposal for mobilisation in order to undertake economic and constructional ventures. (U. Mählert, FDJ 1946 - 1989, Erfurt, Landeszentrale für Politische Bildung Thüringen, 2001; A. McDougall, Youth politics in East Germany. The Free German Youth movement 1946 - 1968, Oxford, Clarendon Press, 2004.)

${ }^{13}$ In the 1987 survey referenced above (n. 9), 81.2\% fully agreed that they wanted to earn more money than in their home employment. At the same time $52.6 \%$ fully agreed that they wanted to contribute to an economically important project of DDR, $42.2 \%$ fully agreed that they wanted to have an exceptional experience, $41.6 \%$ fully agreed that they wanted to acquire special skills in their professional field (Zentralinstitut für J ugendforschung Leipzig, op. cit.).

${ }^{14}$ G. Eggers, H. Matthies, M. Neumann, U. Völker, Abenteuer Trasse, Berlin (Ost), Verlag Neues Leben, 1978.

${ }^{15}$ Zentralrat der FDJ (ed.), Das Bauwerk desJ ahrhunderts, Berlin (Ost), Verlag Neues Leben, 1985.

${ }^{16}$ S. Sampson, 'Ts there an Anthropology of Socialism?', Anthropology Today, Vol. 7, No. 5, 1991, pp. 16-19.

${ }^{17}$ Zentralrat der FDJ , op. cit.

${ }^{18} \mathrm{cf}$. R. Gries, S. Satjukow, Wir sind Helden. Utopie und Alltag im Sozialismus, Erfurt, Landeszentrale für Politische Bildung Thüringen, 2008, p. 11.
} 
German media, a campaign synchronized on behalf of the SED and FDJ , and the young pipeline workers were put centre stage. ${ }^{19}$

Today, a vivid and institutionalised culture of remembrance exists among former pipeline workers, i.e. memory of the pipeline construction does not remain on a private oral level. Instead, it is kept alive by Trassenvereine whose members organise reunions, maintain web pages, provide a discussion forum and run a small museum. Moreover, a few pipeline workers have published memoirs, one of them co-directed a documentary film and one of the associations commissioned a documentary film in three parts. Last but not least, the historical event is mentioned on a great deal of web pages, including Wikipedia and YouTube.

\section{Research Design and the Data}

Combining biographical approaches with the perspective of the ethnography of communication, this paper traces the contexts and linguistic devices by which former pipeline workers narratively construct an East-West juxtaposition. The data corpus comprises of biographical narrative interviews, web pages, internet forums and informal conversations at reunions as well as telephone conversations. The study heavily relies on 'natural data', i.e. data that was generated without the influence of a researcher, for example web pages and Internet forums. With regard to the history of the associations since the mid 1990s, it can be safely said that the increasing spread of Internet access has had a significant impact on the emergence of the community. Only by means of the World Wide Web and by establishing corresponding communicative strategies have former pipeline builders been able to bridge geographical distances between a range of different places of residence. Moreover, and perhaps more importantly, the occupation of virtual spaces has enabled former pipeline workers to reclaim publicity. Likewise, "many marginalized groups of identity formation have been re-appropriating the technological spaces of expression such as [...] the internet to disseminate their own knowledge and specificities". 20

The ethnography of communication "looks at communication from the standpoint of interest of a community itself" and considers "its members as sources of shared knowledge and insight." 21 It is based on the premise that every community has developed a set of "linguistically distinguishable settings" 22 that allow a conclusion to be reached about the structures of the group and the social function of their communicative performance, in addition to the underlying social norms and needs. Thus, it investigates

\footnotetext{
19 Regarding the political discourse, social and economic organisation the railway project Baikalo-Amurskaya Magistral (BAM) across Siberia in the years 1974-1984 was a comparable outstanding flagship construction in the former eastern bloc. cf. V. Mote, 'BAM, Boom, Bust. Analysis of a Railway's Past, Present, and Future', in Soviet Geography, Vol. 31, No. 1, 1990, pp. 321-331; C. Ward, Brezhnev's Folly. The Building of BAM and Late Soviet Socialism, Pittsburgh, University of Pittsburgh Press (Pitt Series in Russian and Eastern European Studies), 2009.

20 B. E. de B'béri, The New Practices of Memory. The Case of Atanarjuat and Indigenous Peoples Council of Biocolonialism, 2005, <http://mokk.bme.hu/centre/ conferences/reactivism/submissions/ ebanda>, accessed on $11^{\text {st }}$ of April, 2009.

${ }^{21}$ D. H. Hymes, Foundations in Sociolinguistics. An ethnographic approach, Philadelphia, Univ. of Pennsylvania Press, 1974, p. 8.

${ }^{22}$ J . J . Gumperz, Discourse Strategies, Cambridge, Cambridge Univ. Press, 1982, p. 43.
} 
the relation between activities of speech and social life by aiming at a "theory of language use". ${ }^{23}$ In addition, the ethnography of communication presupposes that shared linguistic performances of a community or society are historically shaped. Communities are distinguished as to styles of speaking that have to be interpreted in relation to their history. ${ }^{24}$ Concerning the history of linguistic competences, facets of social change, which frequently occur with the expansion of new or alien practices of speaking, are of special interest. Social transformations create a climate in which linguistic routines, conventions and imprints lose their appropriateness 25 and consequently ought to be adjusted. This is especially true if transitions follow a radical historical break, as in 1989. Philologists and linguists have comprehensively investigated the relationship between semantic congruence and conflict of post 1989 East German. ${ }^{26}$ However the connection between language use and social cooperation has been commonly overlooked.

In his work, linguist anthropologist, Dell Hymes, clarified that the basic unit of analysis is a community rather than a language. Accordingly, language is not taken as a linguistic system in its own right but as a social institution. Nonetheless, the study of linguistic features goes beyond a mere content analysis of accounts sought to gain insight into the structural and social characteristics of the field. Rather, communicative features such as utilisation of codes, genres, channels as well as conventions in respect of settings and participants are supposed to be an essential component of social understanding, negotiation, and cooperation. ${ }^{27}$ Thus, the exploration of the field is guided by a systematic analysis of the linguistic repertoire of the community. Conventionalised idiomatic expressions or distinctive syntactical structures not only refer to self-image or worldviews but also often index social institutions or characteristic spaces of social cooperation. Therefore, Hymes described the ethnography of communication as "a semantic analysis embedded in ethnography". ${ }^{28}$ This sociolinguistic perspective implies a conceptualisation of 'biography' and 'narrative' that belong to the realm of the sociology of knowledge.

The community of former pipeline labourers sets itself apart from an "out-group" 29 by strong reference to a shared biographical event. The notion of biography used in this paper is based on three essential premises: First, life courses have to be distinguished

\footnotetext{
${ }^{23}$ D. H. Hymes, 'Models of Interaction of Language and Social Life', in J. J. Gumperz, and D. H. Hymes (eds.), Directions in sociolinguistics, New York, Holt, Rinehart \&Winston, 1972.

24 D.H. Hymes and F. Coulmas, Soziolinguistik. Zur Ethnographie der Kommunikation. Frankfurt-am-Main, Suhrkamp-Taschenbuch-Verl., 1st ed., 1979, p. 177.

25 Ibid., p. 41.

${ }^{26}$ cf. P. Stevenson, Language and German Disunity. A Sociolinguistic History of East and West in Germany 19452000, Oxford, Oxford Univ. Press, 2002; M. W. Hellmann and M. Schröder (eds.), Sprache und Kommunikation in Deutschland Ost und West, Olms, Hildesheim (Germanistische Linguistik,), 2008, pp.192-194; A. Burkhardt and K. P. Fritsche (eds.), Sprache im Umbruch. Politischer Sprachwandel im Zeichen von „Wende“ und „Vereinigung“, de Gruyter: Berlin, New York, (Sprache, Politik, Öffentlichkeit, 1), 1992; U. Fix, D. Barth, F. Beyer, Sprachbiographien. Sprache und Sprachgebrauch vor und nach der Wende von 1989 im Erinnern und Erleben von Zeitzeugen aus der DDR. Inhalte und Analysen narrativ-diskursiver Interviews. Frankfurt am Mainm Lang (Leipziger Arbeiten zur Sprach- und Kommunikationsgeschichte, 7), 2000.

${ }^{27}$ Hymes \& Coulmas, op.cit., p. 7.

28 Ibid., pp. 35- 40.

${ }^{29}$ cf. Gumperz, op.cit., p. 45.
} 
from biographies. 30 Second, biographies are inextricably linked with memory and retrospective interpretations emerging from socio-cultural exchanges, i.e. communication. ${ }^{31}$ Third, biographical research primarily performs narrative analysis. ${ }^{32}$ Correspondingly, enquiry into biographical data deals with accounts that convey "pragmatic knowledge" constructed through "ongoing time-space specific encounters with other (...) actors and bodies of knowledge". 33 The interview settings of the study are therefore understood as a "social encounter" and "communicative event". ${ }^{34}$ It is not presumed that opinions or emotions exist independently of a concrete social situation or observer and can be extracted by means of methodological techniques. Rather, all utterances have to be interpreted in due consideration of the context that is jointly constructed by the interviewer and the interviewee, i.e. all interviews included in the study have to be read against the background of the pipeline builder's yearning for publicity. The interview situation offered them an opportunity to convey their experiences, interests and self-image. The interviews took place under the heading of a biographic interview, i.e. the interviewees were invited to talk about the period of their life when they were working on the pipeline construction. However, topical shifts were always tolerated and taken as a valuable source of insight since the interviewer, in all cases the author of this paper, wanted to learn about the interpretative frames of the community. ${ }^{35}$

Narrated biographical events are taken as "the metaphor, or perspective, basic to rendering experience intelligible". ${ }^{36}$ In general, the term 'narrative' employed in this article refers to reconstructive genres that a group or "communicative network" 37 uses in order to come to terms with past events and more importantly to envision themselves. As a consequence of narrativisation, these accounts are overlaid by retrospective interpretations ${ }^{38}$ due to communicative interaction. The tactics of the method applied here will focus on the concordance of key terms and topoi, i.e. key terms and lines of reasoning will be traced in the different contexts in which they appear. The analysis aims at the identification of topics and their genres as well as lexis and syntactic structures, etc. Following a sociolinguistic conception, genres are considered as a preset of patterns in order to realise and interpret communicative activities. As such, they serve as a repertoire of social knowledge and performances. ${ }^{39}$ In addition to this, the total

${ }^{30}$ G. Rosenthal, Erlebte und erzählte Lebensgeschichte. Gestalt und Struktur biographischer Selbstbeschreibungen, Frankfurt am Main, Campus Verlag, 1995.

${ }^{31} \mathrm{H}$. Welzer, Das kommunikative Gedächtnis. Eine Theorie der Erinnerung, München, Beck (Beck'sche Reihe), 2002, p. 222.

32 cf. C. Kohler Riessmann, Narrative Analysis, Newbury Park, London, New Delhi, Sage Publications (Qualitative Research Methods, 30), 1993.

33 G. Gardner, 'Unreliable memories and other contingencies. Problems with biographical knowledge', Qualitative Research, Vol. 1, No. 2, 2001, pp. 185-204.

${ }^{34} \mathrm{C}$. L. Briggs, Learning how to ask. A sociolinguistic appraisal of the role of the interview in social science research, Cambridge, Cambridge Univ. Press (Studies in the social and cultural foundations of language, 1), 1995.

35 cf., Ibid., p. 49.

${ }^{36}$ Hymes, Foundations in sociolinguistics. op.cit., p. 16.

${ }^{37}$ Ibid., p. 14.

38 cf. J. Bergmann, Flüchtigkeit und methodische Fixierung sozialer Wirklichkeit. Aufzeichnungen als Daten der interpretativen Soziologie', in H. Hausendorf (ed.), Gespräche als Prozess. Linguistische Aspekte der Zeitlichkeit verbaler Interaktion. Tübingen, Gunter Narr Verlag (Studien zur Deutschen Sprache), 2007, p. 44, 46.

39 J. Bergmann, Zur Analyse der Formen moralischer Kommunikation: Konzepte, Methoden, Daten, Transkriptionsmodelle', in J. Bergmann and T. Luckmann (eds.), Kommunikative Konstruktion von Moral, Opladen, Wiesbaden, Westdeutscher Verlag, 1999, pp. 39- 57. 
reservoir of topoi is understood as the connecting link between rhetoric on the one hand and knowledge on the other. Thus, these figures of speech refer to moral convictions and world views. 40

\section{Communicative Reversion to the Past and the Emergence of Communities after 1989}

Since the mid 1990s, former pipeline workers have regularly met in small private circles. In September 1997, the core of that initial group founded the first officially registered association, a few years later a second association was registered. ${ }^{41}$ These two associations and a few smaller groups attract the same pool of people. The "speech community" 42 is characterized by a limited "threshold of members", 43 i.e. only those who worked within the economic venture of pipeline construction can become a participating member of the community.

Prior studies have shown that the collective reflection of shared knowledge that has its roots before 1989 functions as a means of orientation throughout the transformation process as it provides a shared basis in order to consolidate (new) East German communities. ${ }^{44}$ The communicative confirmation of bonding elements, in particular a shared past, has been fundamental to the "construction of a shared fiction". In other words, the identification and labelling of a group is accomplished by appeals to the past. 45

For many former pipeline employees, their period of life and work in the former Soviet Union represents one of the key points of their lives, and thus still connects them to other people who share the same life experience. They notably struggle with an immense loss of prestige that they once enjoyed on an ideological as well as on a material level. They repeatedly state that gas is central to the German economy and is the cornerstone for a lot of things" 46 and that the pipeline provided "an excellent start for the Federal German Republic in the gas business." 47 One interviewee even bewailed that the pipeline construction was not even mentioned in history textbooks. ${ }^{48}$ In particular, people born in the 1950s and early 1960s experienced a remarkable biographical break

\footnotetext{
40 Ibid., p. 43.

41 The splitting up of the community into two associations follows the logic of structure of the economic event. The association Erdgastrasse e.V. addresses or serves former employees of the state owned companies that were in charge of the implementation of the affiliated duties of the venture, i.e. the development of the general infrastructure and dwelling places along the pipeline. The association Erdgastrasse-LT e.V. addresses former employees of companies that were in charge for the construction of the pipeline as such.

42 Briggs, op.cit., p. 61.

43 J. M. Swales, Genre analysis. English in academic and research settings, Cambridge, Cambridge Univ. Press, ed. 13, 1990.

44 cf. D. Boyer, 'Conspiracy, history, and therapy at a Berlin Stammtisch', American Ethnologist, Vol. 33, No. 3, 2006, pp.327-339 (p. 327).

${ }^{45}$ V. Blöcher, 'Ost-West-Vergleiche und ihre moralische Kommunikation', in J. Bergmannand T. Luckmann (eds.), Kommunikative Konstruktion von Moral, Opladen, Wiesbaden, Westdeutscher Verlag, 1999, pp. 87-105.

46 Written notes of a telephone conversation, August 2008, LC, female, 54 years old, pipeline employment 1974-1979, 1985-1992 as mechanic, today production worker in an East German small town.

47 Interview, J uly 2008, DT, male, 57 years, pipeline employment 1986-1989 in fire prevention and industrial safety, today manager of an East German branch of a West German fire prevention enterprise.

48 Written notes of a telephone conversation, LC op. cit.
} 
in 1989. Due to the comprehensive reorganisation of the society, many East Germans witnessed a subjective and objective depreciation of their live experience. ${ }^{49}$ People lost their jobs, degrees lost their value, social networks were destroyed and social and cultural prestige was redistributed. Former pipeline employees, like all East Germans who were adults when the Berlin Wall fell, had to learn new cultural, political and economic rules that were "imported" by West German "development assistants". 50 One of the features that set the pipeline workers' community apart is their exceptional biographical and professional experience in the GDR. The experience of being forgotten constitutes a harsh contradiction to their conviction that their work accomplishments are still of significance today, in terms of the energy supply to entire Germany. The activities of the associations attempt to ease this contradiction by becoming the mouthpiece of the pipeline workers and by providing an infrastructure for consensus building, the formulation of a socio-political agenda and performance of public action. One central strategy is to connect with political and economic actors. In July 2008, the spokespersons of one of the associations participated in a celebration of the anniversary of 35 years of gas supply from the Russian Federation to Germany. Among the guests were the CEO of Gazprom, the German minister of Transport and Traffic and the Russian ambassador to Germany, not to mention many journalists. It can be argued that the associations' practices are more than a sort of nostalgia. Rather, the community actively produces an image of the past with the intention to occupy public spaces, and thus disseminates their knowledge and expresses social and political interests. In this regard, the associations' mission statement reads that their objective is to establish "a link between the past and the future" in addition to contributing to "the informing and education of Germany's citizens". 51

\section{The Narrative Construction of Pride as Resistance to Oblivion}

The legitimate membership in one of the associations is based on "biographical interferences" 52 that are semantically marked. The centre of these semantic markings comprises of the notions Trassenbau (the pipeline construction), Trasse (the pipeline) and Trassenerbauer (the pipeline builders). Starting from their biographical knowledge, the semantic content and "underlying symbolic relationships" 53 among these notions constitute the "network specific discourse conventions" 54 that are, among other things, directed at regaining acknowledgment of their work. In this regard, their narrative alternates between an explicit striving for recognition of their working achievements and resistance towards a loss of prestige as well as regrets at having being forgotten by the German public.

\footnotetext{
49 T. Ahbe, Ostalgie, Zum Umgang mit der DDR-Vergangenheit in den 1990er Jahren, Erfurt, Landeszentrale für Politische Bildung Thüringen, 2005, p. 7.

50 Ibid., p. 34 (author's translation of the German original)

$51<$ http:// www.erdgastrasse-ev.de>, accessed on 16 th of J uly, 2009.

52 F. Schütze, 'Prozeßstrukturen des Lebenslaufs', in J. Matthes, A. Pfeifenberger, M. Stosberg (eds.), Biographie in handlungswissenschaftlicher Perspektive. Nürnberg, Verlag der Nürnberger Forschungsvereinigung, ed. 2, 1983, pp. 67- 129. (author's translation of the German original)

${ }^{53}$ Hymes, Foundations in sociolinguistics, op. cit., p. 138.

54 Gumperz, op.cit.,p. 42.
} 
By providing the communicative infrastructure, the associations establish a connotative unity between the crucial symbols of the community's self image: Trasse does not only refer to a certain element of an energy infrastructure. Among former pipeline builders, the meaning of the term includes reference to a period of time, a social milieu and, more importantly, the meaning is overlaid with emotions. This cognitive and emotional connotation 55 involves a virtually complete object-subject equation. Part and parcel of this equation is the recurrent citing of the pipeline workers' achievements at the time of the venture. Therefore, they do not merely perceive themselves as former employees or workers but as the builders or the constructers as is expressed in the term Trassenerbauer. According to their self-image, they were the most important actors. When naming the key players of the event, they do not refer to economic, technical or political officials, rather they mention blue-collar workers:

Thus, not only were key players like welders, concrete workers, electricians, bricklayers, truck drivers and machinists etc. involved in the construction of the Trasse, but also cooks, saleswomen, cleaning staff, sanitation truck drivers, nurses, librarians and disc jockeys $[. .$.$] etc. 56$

It can be assumed that their self-image is still reminiscent of the political campaigns that accompanied the economic venture in the GDR. Accounts are influenced by "templates of the sphere of socialist propaganda", 57 i.e. the socialist variation of the labourist mobilisation of the working class. Industrial work was ideologically honoured. Thus, economic logic was entangled with political and cultural praxis. ${ }^{58}$ In the pipeline builders' account, blue-collar workers are still endowed with prestige. The object-subject equation of their communicative performance recalls the semantic nexus between technology and work that characterised the ideological construction and agitation of the labour state'. Considering that socialist publications referred to the pipeline builders as Kortschagins, which can be attributed to Nikolai Ostrowksi's "How the steel was tempered", 59 which had been compulsory reading in the school curriculum, it is remarkable that former pipeline builders still greet each other as Kortschagins in internet forums and guest books of the homepages. ${ }^{60}$

The data reveals that former pipeline employees are extraordinarily familiar with the historical media. All interviewees possess the literature on pipeline construction that was published in the 1970s and 1980s. Furthermore, TV programmes, such as the rebroadcast of the 1976 DEFA ${ }^{61}$ production "Begegnungen an der Trasse" (Encounters at the Trasse), are announced on the web pages. In order to come to terms with a

\footnotetext{
55 cf. A. Linke, M. Nussbaumer, P. R. Portmann-Tselikas, U. Willi and S. Berchtold, Studienbuch Linguistik, Tübingen, Niemeyer, ed. 5, 2004, p. 153.

$56<\mathrm{http}$ :/ / www.erdgastrasse-ev.de>, accessed on $16^{\text {th }}$ of July, 2009. (author's translation of the German original: „So waren nicht nur die Leistungsträger wie Schweißer, Betonbauer, Elektriker, Maurer, Kraftfahrer, Maschinisten usw. am Bau der Trasse beteiligt, sondern auch Köche, Verkäuferinnen, Reinigungskräfte, Fäkalienfahrer, Krankenschwestern, Bibliothekarinnen, Discjockeys [...] usw.")

${ }^{57}$ Gries and Satjukow, op.cit., p. 46 (author's translation of the German original).

58 A. Lüdtke , ,Helden der Arbeit: Mühen beim Arbeiten, Zur missmutigen Loyalität von Industriearbeitern in der DDR', in H. Kaelbe, J. Kocka and H. Zwahr (eds.), Sozialgeschichte der DDR, Stuttgart:,Klett-Cotta, 1994, p. 189.

59 Zentralrat der FDJ , op. cit.

$60<\mathrm{http} / /$ www.razyboard.com/system/user_mcsamel.346698-2109822-0.html $>$, accessed on $14^{\text {th }}$ of December, 2009.

61 The Deutsche Film-Aktiengesellschaft was the public-owned film studio in DDR.
} 
fundamental biographical event, former pipeline workers rely on these media in order to substitute the absence of information. Thus, the socialist elite's interpretations still have an influence on their current self-perception.

Even more remarkable is the fact that the writers on the associations' web pages only make use of the term Leistung (performance, achievement) in the same sense as the GDR media did when reporting on the event. Leistung can hardly be translated into English by one equivalent term. It mainly refers to skills and capacities of a person in the work or professions he does as well, as the results. In addition, Leistung is closely connected with discipline. Last but not least, the term is equated with duties. On the web pages, the notion Leistung is only applied in the latter context in order to describe, name and enumerate the duties the GDR had to fulfil within the framework of the COMECON contract.

Since the breakdown of socialism in 1989, it can be argued that people are cautious about speaking explicitly about the achievements of the GDR. 62 The underlying data corpus reveals that former pipeline workers do not use the terms Leistung or Errungenschaft (both meaning success or accomplishment). Instead, they use superlative constructions and hyperbolic speech, which relies on the connotative power of the semantic and grammatical structures. The historical overview of the Trassenbau (pipeline construction) on the webpage of one of the main associations reads:

The construction of the gas pipelines was the largest construction project in the history of the GDR and to this day the gas that supplies Germany with energy runs through the pipes [...] (emphasis added)

Referring to the second construction phase the author continues:

The crossing of Dniester river near Gorodenka and the construction of a compressor station in Wolowez on top of a $700 \mathrm{~m}$ high mountain were in actual fact tremendous feats[...] In 1984, the GDR aquired a third section. This time in the Ural Mountains, where the demands put on the pipeline builders were enormous [...] Here, the pipeline lads were called upon to produce a masterpiece [...] In all wind and weathers,welders and metal workers had to do the hardest work. [...] Precision work had to be done [...] everything needed to be exactly orchestrated[...]" (emphasis added) ${ }^{63}$

This passage was selected for the reason that it combines several linguistic practices that in their relatedness reappear in several contexts in the collected data and accordingly constitute the distinctive linguistic performance. It can be argued that superlative constructions (largest construction, hardest work, etc.) and hyperbolic speech

\footnotetext{
${ }^{62}$ W. Oschlies, "Wir sind das Volk". Zur Rolle der Sprache bei den Revolutionen in der DDR, Tschechoslowakei, Rumänien und Bulgarien, Köln, Böhlau, 1990, p. 32.

63 <http:// www.erdgastrasse-ev.de>, accessed on $16^{\text {th }}$ of July, 2009. (author's translation of the German original: „Der Bau der Erdgasleitungen war das größte Bauprojekt in der Geschichte der DDR und durch die Leitungen fließt heute noch das Gas, welches Deutschland mit Energie versorgt. [...]So war die Dnestr-Überquerung bei Gorodenka und der Bau der Verdichterstation in Wolowez auf einen über $700 \mathrm{~m}$ hohen Berg doch schon was Gewaltiges [...] Bereits 1984 erhielt die DDR dann noch einen dritten Bauabschnitt. Dieses Mal ging es in den Ural und die Anforderungen an die dort tätigen Trassenerbauer waren enorm [...] Ein Meisterstück hatten die Trassenkumpels hier zu leisten [...]Bei Wind und Wetter haben die Schweißer und Schlosser [...] schwerste Arbeit geleistet [...]Präzisionsarbeit musste geleistet werden [...] Alles musste exakt beherrscht werden [...]")
} 
(tremendous, enormous, masterpiece, precision work, exactly orchestrated, etc.) are a linguistic means to stress performances and accomplishments by evoking connotations connected with this particular lexis and these grammatical structures. The selfrepresentation as a productive workforce has two effects. First of all, former pipeline workers detach their narrative from the ideological and political context the project was embedded in. As was argued above, this image can hardly be perpetuated, due to intertextual features of campaigns that were led by the Socialist Party and the mass youth organisation. Secondly, and more importantly, references to accomplishments and hard work express pride that in conjunction with other topics provides the basis for the striving for recognition. The text cited above clearly points to the significance of the pipeline for entire Germany: "to this day the gas that supplies Germany with energy runs through the pipes". It is not just any gas, and it is not only a certain percentage of the energy supply provided by the devices, which were constructed at the time of the GDR. By syntactic means (i.e. adding the article "the") the writer implies that Germany's energy supply could not be realised without this pipeline.

Reference to accomplishments and performances on the one hand and the significance of the pipeline for all of, i.e. reunified Germany on the other hand make up a semantic complex that expresses pride. In this regard, the invitation to a reunion of former pipeline builders in 2009 reads:

Today, we number hundreds of pipeline builders of the LT, who meet every second year in Neuseddin and have therefore found a home' again [...] the pressure put on us in today's society gets harder. More and more experience the fear for one's existence. When looking around in our old brigades and considering the fates of several of our colleagues, it is more than understandable that we crave familiarity and reliability. Whatever you are or are not, whatever you own or do not own, you will be the one you once were when coming to the camp on these dates. Each of us, who performed a decent job at the Trasse and respected the premises of companionship, can be proud of this unforgettable time! 64

Former East German employees of the COMECON pipeline construction take pride in the work they experienced during socialist times. However, the most striking finding of the data analysis was that the expression of pride intermingles with interpretations and judgements of the transitions and the unification of Germany, as well as the juxtaposition of 'East and West'. The caesura of 1989 and the reunification in 1990 are associated by the pipeline workers with the experience of being forgotten by the German public, or as the co-founder of an association put it: "No one cared about it anymore. Whereas in the GDR times it was of great importance, no one cared about it anymore."

$64<$ <ttp://www.erdgastrasse-ev.de/aktuell/echo_2009.pdf>, accessed 28 $8^{\text {th }}$ of August, 2009. Written by KC, chairman of the association, circa 45 years old, pipeline employment 1985-1990 as cook, today chef in a West German middle town. (author's translation of the German original: „Heute sind wir mehrere hundert Trassenerbauer des LT, die sich jedes zweite Jahr in Neuseddin treffen und wieder eine „Heimat“ gefunden haben. [...] Der Druck in der heutigen Gesellschaft auf jeden von uns wird stärker. Immer mehr kennen das Problem der Existenzangst. Wenn wir in unsere ehemaligen Brigaden schauen und die Schicksale einiger unserer Kollegen betrachten, so ist es nur mehr als verständlich, wenn wir uns nach Vertrautem und nach Beständigkeit sehnen. Egal was du bist oder auch nicht bist, egal was du besitzt oder auch nicht besitzt, wenn du für diese Tage auf diesen Platz kommst, bist du der „Alte“ von damals! J eder von uns, der an der Trasse seine Arbeit anständig vollbracht und die Prämissen einer Kameradschaft geachtet hat, kann auf diese unvergessliche Zeit stolz sein!) 
In a later sequence the interviewee explains the foundation of the associations: "[...] and then we said, man, it can't be true that it's all over!"65

The construction of pride, by stressing the significance of the pipeline for all of Germany and reference to accomplishments and hard work, provides the basis for the strive for recognition. In any case, the survival of socialist symbols in the communicative performance of former pipeline workers provides evidence that life experiences during socialism "leave traces and imprints" 66 that most likely have an impact on judgements about post-socialist transformations. Czech anthropologist Petr Lozoviuk described the real existing socialism as a complex ideological, political and economical system that in the long term had culture shaping effects. ${ }^{67}$ Polish sociologist Piotr Sztompka noted that "the institutions were the quickest to change after 1989"68 whereas "the legacy most resistant to change, the one featuring the most inertia, is to be found in the culturalmental sphere: the domain of rules, values, norms, shared beliefs, ingrained habits of the heart' and subconscious reflexes". ${ }^{69}$ One challenge for many East Germans in the course of the transition was to safeguard a positive identity and the construction of a new self-image against the background of profound biographical and historical upheaval in 1989. The following chapter will deal with semantic interrelations between the construction of self-images and the expression of divisions between 'East and West' that are accompanied by markedly negative sentiments attributed to West Germans and Western Europeans.

\section{The Communicative Maintenance of Divisions between East and West}

It has been shown that former pipeline builders express pride about their working biographies by narratively connecting pride with accomplishments and by highlighting the difficult working conditions they faced. One of the central strategies in creating a positive self-image is to emphasize differences between working within the GDR and within the venture of pipeline construction, in particular with regard to profitability and effectiveness. By using this strategy, they seek again to detach their experience from the ideological and political context the project was embedded in. Furthermore, the job requirements are implicitly put on the same level with those in market economies. One interviewee states:

And in 86, 87 [...] they put much more emphasis on the effectiveness of our work than before, which meant we were compensated according to our effectiveness, and that was a huge discrepancy, since it was a contradiction of what the citizens of the GDR, who were employed out

\footnotetext{
65 Interview, LC, op. cit. (author's translation of the German original: „Da hat sich keiner mehr drum geschert. Zu, zu DDR-Zeiten große Bedeutung, da hat sich keiner drum geschert [...] und dann haben wir gesagt, man das kann doch nicht sein, dass das alles gewesen ist.")

66 P. Sztompka, 'The Ambivalence of Social Change in Post-Communist Societies', Södertörn Lectures 1, 2007 , p. 22.

${ }^{67}$ P. Lozoviuk, 'Realsozialismus als Kulturtyp und Möglichkeiten seiner ethnologischen Erforschung.', Volkskunde in Sachsen, Vol. 17, No. 1, 2004, pp. 161-176).

68 Sztompka, 'The Ambivalence of Social Change', op.cit., p. 27.

69 P. Sztompka, 'The cultural core of post-communist transformations', in T. Boje (ed.), European Societies: Fussion or Fission. London, Routledge, 1999, pp. 205-215.
} 
there, had learned in the so-called lessons of socialist labour and in the training courses organised by the party [...].70

Nevertheless, the narrative shows that their pride in their achievements is a broken pride because it is intermingled with negative experiences of the disappearance of socialist order and the unification. An interviewee describes the events in 1990 as follows:

Of course, now a few people thought they could buy 100 meter pipe for 1.50 [DM]. For example, Wintershall. That was the troop that bought the thing or was at least interested. Because I saw then in Berjosowska that big four-wheel drive cars showed up [...] from Essen and other West German cities, as if to say that little piece of shit. [...] And that's exactly it. They wanted to acquire the Trasse for peanuts. But what the Trasse is worth now, is proved every single day! ${ }^{71}$

In this quotation, the individuals clearly disappear behind a stereotype, a distinctive narrative practice to express the opposition between 'easterners and westerners' in post 1989 Germany, a dichotomising practice that has been discussed in sociolinguistics. ${ }^{72}$ In this case, it is the "East German worker" as oppose to the "West German capitalist", where it is inferred that the latter is patronising and supercilious. At the same time, the teller creates a social situation through narrative, in which West Germans not only appear as dominant over East Germans, but also as invaders in the context of the pipeline takeover. Recollection of the biographical past is always influenced by the current convictions of the interviewee. ${ }^{73}$ As such, the repetitive reference to the economic significance of the pipeline is inextricably linked to experiences at the time of the reunification process. Pipeline workers experienced the reunification and transformation process as a challenge to their self-image, their societal knowledge and more importantly their self-confidence. Whereas the political elites of the GDR paid homage to them in order to create hero workers' for the labour state, they experienced a dramatic loss of prestige after 1989. In connection to this, the mission statement of one of the associations reads:

A lot of [...] the men and women had to give up their long term employment in assembly work in Russia due to the fall of the Wall, the reunification of Germany and the related economic changes. They went back to a completely reorganised and changed Germany

\footnotetext{
70 Interview, DT, op. cit. (author's translation of the German original: „Und 86, 87 [...] wurde viel stärker auf die Wirtschaftlichkeit unserer Tätigkeit Wert gelegt als das vorher der Fall war, das heißt wir wurden richtig nach Effektivität, nach Produktivität abgerechnet und das war ein großer Zwiespalt, weil es im Widerspruch stand zu dem, was die Bürger, die dort gearbeitet haben aus der DDR mal in den so genannten Stunden der sozialistischen Arbeit und in den Parteilehrgängen gelernt haben [...]")

71 Interview, July 2008, HV, male, 62 years old, pipeline employment 1987-1990 as car mechanic, today selfemployed driving instructor in a suburb of an East-German major city. (author's translation of the German original: „Natürlich haben nun einige gedacht, sie können so ein 100 Meter Rohr für 1,50 kaufen. Zum Beispiel Wintershall. Das ist ja die Truppe, die das Ding gekauft hat, beziehungsweise, die sich dafür interessiert hat. Denn ich habe es ja auch damals noch erlebt in Berjosowka, dass dann große Geländewagen vorgefahren kamen [...] also aus Essen und anderen westdeutschen Städten und so nach dem Motto, na das bisschen Scheiße [...] Und das ist eben, dass sie die Erdgastrasse dann für'n Appel und n Ei kaufen wollten. Und was die Erdgastrasse nun Wert ist, beweist sich ja jeden Tag.")

72 Stevenson, op.cit., p. 207.

73 A. Lehmann, Erzählstruktur und Lebenslauf. Autobiographische Untersuchungen, Frankfurt am Main, Campus Verlag, 1983, p. 101.
} 
and were left alone with their reunification problems. By means of discussions, exchange of thoughts, support of gatherings and the organisation of reunions, the association wants to assist in the understanding and coming to terms with the past. ${ }^{74}$

In order to raise public awareness, the associations are eager to appear in the media. Before every reunion, the public relations representatives contact newspapers and television stations. Nevertheless, as one PR representative put it in an interview, his attempts have not been crowned with success. Disappointed, he admits: "Probably we are not that important anymore, we are no longer on top of the priority list". ${ }^{75}$

The unification of Germany has negative connotations among former pipeline workers, ranging from a voicing of disappointment to an, in principle, affirmation of the reunification to an outright denial of identification with the GDR. In all biographies, 1989 appears as a crucial turning point that splits up their "overall biographical concept"76 in two entities: before and after 1989. Within the course of the transformation process, their self-images were massively challenged and they faced a feeling of inferiority that opened the way to juxtapositions of East Germans and West Germans, of socialist and non-socialist societies that represent different value systems. The narrative practice of comparisons works by means of deictic devices whose denotational meaning strictly depends on the biographical context of the community. ${ }^{77}$ Deictic comparisons often have an implicit character, i.e. the referential other (a person or state of affairs) is not explicitly named. Yet deictic devices are understandable if the interactants - be it writer and reader or speaker and hearer - share the same background knowledge that was acquired through socialisation or just in the course of a conversation or text. Deictic practices of former pipeline workers primarily include temporal and personal indexicals (before versus after 1989/the fall of the wall; they versus us, West Germans versus East Germans, and West European capitalists versus workers from the GDR). In most cases the attribution of negative qualities to the other in binary oppositions implies the possession of corresponding positive qualities by the self. ${ }^{78}$ One interviewee describes the changes in 1989:

\footnotetext{
$74<$ http:// www.erdgastrasse-ev.de>, accessed on 16 th of July, 2009. (author's translation of the German original: „Viele der o. g. Männer und Frauen mussten ihre jahrelange Montagetätigkeit in Russland durch den Wegfall der Mauer, der Wiedervereinigung Deutschlands und den dadurch entstandenen wirtschaftlichen Veränderungen aufgeben. Sie gingen zurück in ein völlig neu organisiertes und verändertes Deutschland und wurden mit ihren Wiedereingliederungsproblemen alleingelassen. Auch hier soll der Verein durch Gespräche, Gedankenaustausch, Unterstützung von Zusammenkünften und das Organisieren von Treffen dazu beitragen, die Vergangenheit zu verstehen und aufzuarbeiten.")

75 Interview, August 2009, J S, male, 45 years old, pipeline employment 1987-1990, today project manager in a West German small town, moved to West Germany in 1990. (author's translation of the German original: „Und wahrscheinlich sind wir nicht mehr so wichtig, auf der Prioritätenliste sind wir nicht mehr ganz oben.")

76 Rosenthal, op.cit., p.85.

77 Deictics are expressions that are contextually bond. Therefore the meaning depend on the occasion of their use as well as other contextual features such as the biography of the teller. Deictic devices "commit a speaker to set up a frame of reference around himself or herself. (J. I. Saeed, Semantics, Malden, Mass.: Wiley-Blackwell (Introducing linguistics, 2), 2009. In other words they index complementary aspects of the utterance. Deixis includes pronouns, demonstratives, and spatial, temporal and other adverbs referring to equivalence or "counterpart relations". Deixis is closely related to indexicality, i.e. utterances that indicate or refer to some state of affair. (W. F. Hanks, 'Explorations in the Deictic Field', Current Anthropology, Vol. 46, No. 2, April 2005, pp. 191-220.)

78 Stevenson, op. cit., p. 207.
} 
Before the change over, when we were dismantling, we put everything into a container and brought it back home. After the change over, they sold off everything that wasn't nailed down. ${ }^{79}$

The juxtaposition of procedures before and after 1989 implies a comparison of operating principles in socialist and capitalist systems that, in this case, reflects a comparison of East German and West German operating principles after the venture had been taken over by the West German companies. The interviewee represents East Germans as morally superior, whereas West German principles appear as wasteful.

All in all, the account of the events in 1989 can only be understood against the backdrop of high unemployment that particularly affected the East Germans after the fall of the wall:

And that's how it was, more and more people were dismissed. I don't know if it is true or not, I just know it from hearsay that there was supposedly a Swiss consultant [...] who had got 10000 marks per dismissed man. ${ }^{80}$

Prior studies from sociolinguistics and anthropological linguistics have shown that rumours give important insights into popular moods. ${ }^{81}$ Thus the quotation can be comprehended as an interpretative pattern that attributes western economic systems as anti-social. A sequential analysis of the interview shows that by juxtaposing "East and West" the interviewee legitimizes his own profession to a GDR identity. An account about his last trip to Russia in 2008 reads:

And then one day a woman came and asked me - East or West Berliner? I replied - I am a GDR citizen. Then I said - have you ever seen a West German here? Then I said -No, you see! - And none of them will come here, and none of them wants to come here!"82

Statements like the one cited above can be considered as an extreme standpoint and do not represent the general opinion of the group. Rather, the community of former pipeline workers is characterised by diversity with regard to their political attitudes that are actively negotiated among them, for instance in their internet forum. Nonetheless, the experience of having been forgotten by the public is a shared and apparently painful experience that is inextricably connected with judgements about the reunification process and related characterizations of West Germans. Even the former pipeline workers who voice unambiguous approval of Germany's reunification follow this line of argumentation. A former employee who left the GDR for the West in the mid-1980s

\footnotetext{
79 Interview, LC, op.cit. (author's translation of the German original: „Wenn vor der Wende ein Rückbau war, dann ging alles in nen Container und wurde wieder nach Hause gefahren. Nach der Wende, ja haben se, was nicht niegelnagel-fest war eben verhökert, ja.")

80 Interview, HV, op.cit. (author's translation of the German original: „Und so ist es dann auch gewesen, es wurden immer mehr entlassen, denn ich weiß nicht, ob das stimmt, ich habe es auch bloß gehört, dort sollte es einen Schweizer Unternehmensberater gegeben haben, [...] der hätte dann pro entlassenem Kumpel 10000 Mark gekriegt.")

81 A. Lehmann, Reden über Erfahrungen. Kulturwissenschaftliche Bewußtseinanalyse des Erzählens, Berlin, Reimer Verlag, 2007, pp. 99-103.

82 Interview, HV, op.cit. (author's translation of the German original: „Und dann kam mal eine Frau Ost- oder Westberlin? Ich sag Du ich bin DDR-Bürger. Ich sag, hast du hier schon mal einen Westbürger hier rum rennen sehen? Nee, sag ich siehste. Hier kommt auch keiner her, hier will auch keiner herkommen.")
} 
after her partner spent four years as a political prisoner, articulated her disappointment about her West German co-workers' lack of knowledge regarding the pipeline construction by generalising: "Wessis don't even know about it" 83 . Despite the fact that through the act of unification in 1990, the political opposition 'GDR versus FRG' was dissolved, the dichotomy 'East versus West' has remained and up to today functions as an "interpretative resource in interaction". The "Ossi-Wessi-dichotomy" 84 attributes negative qualities by each to the other. One popular East German ascription to the West Germans is that of a "Besserwessi" (know-all) Another East German assertion is that West Germans are ignorant of East German affairs. ${ }^{85}$ At most, these narrative strategies are "an opportunity for former East Germans to salvage dignity and reassert self-esteem in the face of a dominant other [...], but at the same time they imply an acknowledgement of their subordination." 86 To make themselves heard and to have their own experiences acknowledged, a mere expression of negative attributions to West Germans would probably have a counterproductive effect. Instead, linguistic studies have shown that East Germans package their personal criticism in an analysis of current social problems. ${ }^{87}$ Likewise, the pipeline worker's associations integrate a reference to the high unemployment rate among East Germans in their mission statement and thus offer a more objective critique of the political situation in the unified Germany.

At the same time, the community of former pipeline workers appears to be markedly diverse concerning their political attitudes, life experience when living in the GDR, motives for working for the GDR's prestigious project of pipeline building and also in their careers after 1989. Today, former pipeline employees state that they applied to work at the venture in order to get an apartment or a university place, others again admit upfront that their motivation was aligned with the socialist ideas of the time, i.e. they were active and convinced members of the SED or FDJ. What holds the group together is a strong and meaningful biographical frame, i.e. the exceptional experience of several years of life and work in the Soviet Union. The infrastructure of the community meets the social need to come to terms with the GDR past and the transitions after 1989 within a familiar community of which all members possess a minimum of shared knowledge. A look at the Internet forum reveals that those pipeline workers who contribute to the communicative infrastructures of the associations today, discuss rather controversial topics, concerning past and present day Germany. A discussion from 2005 reads:

Pawel: Inspired by today's programme "KLIPPund KLAR - What remains of GDR" on $\mathrm{RBB}^{88}$ I was thinking, what really does remain of the, of our GDR?

Hajo: There are a few "trademarks" that have remained [...] the TV-Tower [...] the reconstructed Semper Opera House, [...] or region-wide Kindergarten infrastructure in the East - also our pipes still sit in the Russian-Ukrainian soil. But honestly. What

\footnotetext{
83 Written notes of a telephone conversation, February 2008, EU, female, 58 years old, pipeline employment 19751979 as post office clerk, today post office clerk in a West German major city. (author's translation of the German original)

${ }^{84}$ Stevenson, op. cit., p. 208.

85Ibid., p. 208.

86 Ibid., p.209.

${ }^{87}$ Ibid., p. 210.

88 Rundfunk Berlin Brandenburg (Berlin Brandenburg Broadcasting)
} 
remains of Spartacus, [...] Martin Luther, the German peasant wars, the November revolution or the general turmoil of 1989? Hardly anything tangible.

Pawel: I don't approve of the formulation “turmoil of 1989", that wasn't turmoil but a peaceful revolution. Not with weapons, but peacefully with candles! I was there! 89

It is remarkable here, that the contributor who overtly confesses to a positive interpretation of the events of 1989, emphasises that the forum participants are dealing with "our GDR". After 1989, the public discourse about the GDR and its citizens was, above all, carried out by two groups of actors: West German intellectuals, journalists, and politicians on the one hand and the new East German political elites on the other, namely those who had been constrained, oppressed and victimised by those who had held power in the one-party system. Within this climate, West German actors characterised the GDR primarily as a "criminal dictatorship" and a "ragged economy", whereas East German opponents of the SED regime focussed on the repressive circumstances they had suffered from. Citizens of the GDR were often classified as authority-oriented, dependent ${ }^{90}$ and, against the background of ideologically induced full employment within the GDR, also as an unproductive workforce. However, these labels of the GDR and its citizens did not fit the experience of the majority of those who lived in the GDR who tried to make the best of it against all odds. ${ }^{91}$ In that social climate, one significant reaction towards the challenges of the transformation process has been a sentimental renaissance of symbols of the GDR past ${ }^{92}$ or, as in the investigated case here, a biography-based appeal to the past. Negotiations of the past can be motivated by the need to understand and come to terms with history and also by the attempt to represent one's own self-image towards others. ${ }^{93}$ With regard to social consciousnesses in post-communist societies it is highly relevant, according to Piotr Sztompka, how East-Central European countries disposed of socialism and which kind of "becoming the west" they chose. ${ }^{94}$ In comparison to other post-socialist countries, the GDR represents a "unique case", since after the fall of the Berlin Wall it was simply incorporated into the Federal Republic of Germany in 1990.95 The communicative practices of former pipeline builders signify the necessity of coming to terms with the social changes after 1989, in particular the rearrangement of the social prestige order as a result of the reunification of the two Germanys.

\footnotetext{
$89<\mathrm{http}$ // www.razyboard.com/ system/ morethread-was-bleibt-mcsamel-351852-5581679-0.html>, accessed $14^{\text {th }}$ of December, 2009. (author's translation of the German original: Pawel: Inspiriert von der heutigen KLIPP \& KLAR Was bleibt von der DDR? - Sendung im RBB kam der Gedanke, was denn nun wirklich von der, von unserer DDR übrig geblieben ist. Hajo: Es gibt schon einige "Schutzmarken", die geblieben sind [...] der Fernsehturm, [...] die neu aufgebaute Semperoper, [...] oder die im Osten flächendeckenden Kindergärten - auch unsere Rohre liegen ja noch im russisch-ukrainischem Boden. [...] Aber mal etwas ernster. Was blieb übrig von Spartakus, [...] Martin Luther, dem deutschen Bauernkrieg, der Novemberrevolution oder auch von dem allgemeinen Aufruhr 1989? Kaum etwas, was man mit den Händen greifen kann. Pawel: Der Formulierung „Aufruhr 1989“ kann ich nicht zustimmen, das war kein Aufruhr, sondern eine friedliche Revolution. Ohne Waffen, sondern friedlich mit Kerzen! Ich war dabei.)

90 Ahbe, op.cit., p. 42.

91 T. Lindenberger, 'In den Grenzen der Diktatur: Die DDR als Gegenstand von Gesellschaftsgeschichte', in R. Eppelmann, B. Faulenbach, U. Mählert (eds.), Bilanzen und Perspektiven der DDR-Forschung, Paderborn, Verlag Ferdinand Schöningh, 2003, p. 240.

92 Ahbe, op. cit., p. 41.

93 Rosenthal, op. cit., p. 86.

94 Sztompka, The ambivalence of social change, op. cit., pp. 26-27.

95 Ibid., p. 27.
} 


\section{Conclusion}

The community of former pipeline workers sets itself apart from an out-group by strong reference to a shared biographical event. Pipeline workers experienced the reunification and transformation process as a challenge of their self-image, their societal knowledge and more importantly self-confidence. Whereas the political elites of the GDR paid homage to them in order to create hero workers for the labour state, they experienced a dramatic loss of prestige after 1989. Thus, the pipeline workers' narrative performance alternates between striving for recognition of their achievements and resistance towards a loss of prestige and being forgotten by the German public. As a result, their experience of feeling undervalued is inextricably linked to the narrative construction of deictic divisions between 'East and West'.

The element that links narrations on depreciation to narrations on divisions is the expression of pride. It is used as a means of positive self-assertion in order to claim official recognition of "their" piece of workmanship i.e. the pipeline. The narrative construction of pride is clearly reminiscent of socialist lines of argumentation, i.e. the representation of labourers as economic key players that leads to an object-subject equation.

The construction of divisions between 'East and West' in the narratives of the pipeline workers can be traced back to a worldview gained within the GDR as well as their experience of the reunification process. In any case, the interpretation of the communicative practices of former pipeline builders must not be reduced to a merely nostalgic or even revisionist appeal to the GDR past. The topics discussed within that community, rather, provide evidence of the social need of coming to terms with the GDR past and, in particular, the unification of Germany and the related transitions. Therefore, the communicative practices of former pipeline builders can be understood as a collective coping strategy used in order to make sense of the biographical break of 1989, and to ease the experience of the loss of prestige and the invalidation of their values.

The former pipeline workers' critique of East German transformations and judgements about unification are highly informed by their unique working life experienced in former socialist East Germany. However, an overhasty equation of memory, which does not fall within the scope of oppression and opposition, to nostalgia, in the sense of an idealisation of socialism, would all too easily simplify the complex sensitivities and multi-layered life experiences of those generations who have had to integrate a comprehensive systemic change into their self-image. 
